\title{
Story of Bisphenol S - Steps from Bad to Worse
}

\author{
Tereza Žalmanová ${ }^{1}$ - Kristýna Hošková ${ }^{1}$ - Jan Nevoral $^{2}$ - Š́rka Prokešová ${ }^{1}$ - \\ Kateřina Zámostná ${ }^{1}$ - Zora Kotíková ${ }^{3}$ - Jaroslav Petr ${ }^{4,5}$ \\ 1 Czech University of Life Sciences Prague, Faculty of Agrobiology, Food and Natural Resources, Department of Veterinary \\ Sciences, Kamýcka 129, 16521 Prague 6 - Suchdol, Czech Republic \\ 2 Biomedical Center, Faculty of Medicine in Pilsen, Charles University in Prague, alej Svobody 1655/76, 323 00 Pilsen \\ 3 Department of Chemistry, Faculty of Agrobiology, Food and Natural Resources, Czech University of Life Sciences in Prague, \\ Prague 6-Suchdol, Czech Republic \\ 4 Institute of Animal Science, Přátelství 815, 10400 Prague-Uhřiněves, Czech Republic \\ 5 corresponding author Jaroslav Petr: petr@vuzv.cz
}

Received $20^{\text {th }}$ August 2015; accepted $15^{\text {th }}$ February 2016

\section{BISFENOL S - P̌̌ÍBĚH POLITOVÁNÍHODNÉ SUBSTITUCE}

ABSTRAKT Žijeme v „době plastové“. Obrovské množství plastů vstupuje do životního prostředí a z tohoto materiálu se uvolňuje řada chemikálií s endokrinně disrupčními účinky. Bisfenol A (BPA) je znám jako jeden z takových účinných endokrinních disruptorů uvolňovaných z plastů. Tato látka vykazuje široké spektrum negativních efektů na zdraví zvířat i lidí. Proto bylo používání BPA v řadě lidských oborů omezeno a u mnoha výrobků je garantováno, že BPA neobsahují. BPA může v plastech chybět, jen pokud je nahrazen jinými látkami. Jako náhrada za BPA se často používá bisfenol S (BPS), i když jeho endokrinně disrupční účinky jsou prozkoumány jen velmi málo. Jako chemikálie, jejíž používání podléhá mnohem slabší legislativní regulaci než její předchůdce, je nyní BPS používán v mnoha materiálech. Nově získávané poznatky ale stále jasněji ukazují, že BPS není zdaleka bezpečná látka. Nenápadná náhrada BPA za BPS může být vnímána jako zlepšení. Ale zdá se, že tomu přesně naopak. S tím, jak se BPS šírí naším „do plastu zabaleným“ světem, jsme se jen dostali z bláta do louže.

KLÍČOVÁ SLOVA antropocén; endokrinní disruptory; bisfenol A; bisfenol S; politováníhodná náhrada

ABSTRACT We are living in the "Age of Plastics". A vast amount of this material enters the environment, with chemicals released from the bulk of this matter often exhibiting endocrine-disrupting effects. Bisphenol A (BPA), originating from plastics, is well-known as such a potent endocrine disruptor. This compound exhibits wide spectra of detrimental effects on animal and human health. For these reasons, the use of BPA has been limited in many human activities and bisphenol A-free products are now guaranteed. As a key compound of many plastics, BPA could not be omitted from plastics without being replaced by other chemicals. Bisphenol S (BPS) is often chosen as a substitute for BPA, although its endocrine-disruptive effects are poorly known. As a chemical facing much less stringent legislation than BPA, its forerunner, BPS is now widely used in many materials. However, an increasing volume of new knowledge indicates that BPS is far from safe. The "silent" substitution of BPA with BPS could be perceived as an improvement. However, the converse appears to be true. With BPS spreading through our "plastic-encased" world, we are going from bad to worse.

KEY WORDS anthropocene; endocrine disruptors; bisphenol A; bisphenol S; regrettable substitution

\section{INTRODUCTION}

For several past centuries, mankind and its activities have become such an important factor shaping the environment of our planet that the term ,Anthropocene' is starting to be used for the present period of human history (Monastersky, 2015). Besides other phenomena, the excessive use of plastics and their quick integration into the environment, including the seas and oceans, has become characteristic of the current stage of development of human civilisation (Jambeck et al., 


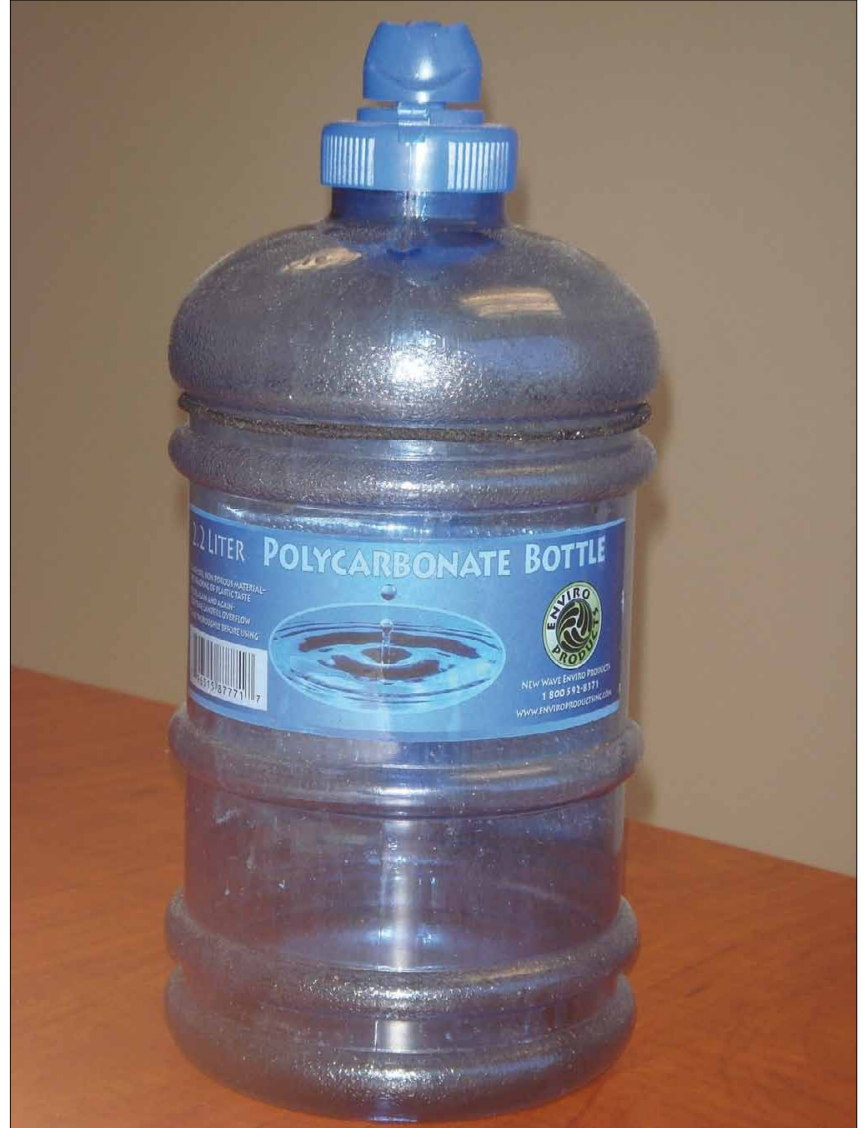

Figure 1. Bisphenol A is primarily used to make plastics, such as this polycarbonate water bottle. (Source WikiMedia)

https://upload.wikimedia.org/wikipedia/commons/d/d7/Polycarbonate_water_bottle.JPG

2015). Microplastic - plastic particles smaller than $5 \mathrm{~mm}$ accumulate in the oceans (Rochman et al., 2013), are trapped in the polar ice (Obbart et al., 2014) and integrate into living organisms (Wright et al., 2013; Watts et al., 2014). In some cases, plastics become part rocks which are known as plastiglomerates (Corcoran et al., 2013).

Hormonally active substances are released from plastics into the environment (Vandeberg et al., 2012). These chemicals are known as endocrine disruptors (Colborn, 2004). They are defined as ,any chemical that can interact directly or indirectly with the endocrine system, and subsequently result in an effect on the endocrine system, target organs and tissues" (EFSA, 2012). It is estimated that exposure to endocrine disruptors in inhabitants of the European Union results in annual damages amounting to at least $€ 157$ billion, both in healthcare costs, as well as in lost earning potential. The upper limit for these estimates of the damages is around $€ 270$ billion, representing $2 \%$ of the gross domestic product of European Union countries (Trasande et al., 2015).

Bisphenol A (BPA), which was used as an important component in many materials including various plastics, represents one of the substances which completely fulfils the definition of endocrine disruptor. Due to fear of the endocrine-disrupting effects of BPA, this chemical has been replaced in some materials with other substances. Products made from these materials are guaranteed as BPA-free.

But we have to ask what chemicals have replaced BPA in BPAfree products? One of the substitutes for BPA is bisphenol S (BPS). Despite there being only limited data on the endocrinedisrupting properties of BPS, this chemical is not subjected to such strict regulation as BPA. Today BPS is used in bulk and its presence has been demonstrated both in the environment and in the human body. This begs the question whether this substitution of bisphenol $\mathrm{S}$ is a step in the right direction.

\section{BISPHENOL A}

Bisphenol A is one of the most mass-produced chemicals in the world. Annually about 4 million tons of BPA is produced and about 100 tons is released into the environment every year (Vandenberg et al., 2010). This substance was first synthesised in the late 19th century. In the 1930s, it was tested as a potential oestrogen, but was not of practical use. The industrial production of plastics with BPA began in the 1940s and 1950s. BPA was quickly used as a component of polycarbonate plastics for food containers and in epoxy resins e.g. in dental fillings. Further widespread use of BPA occurred in recycled paper and in paper for thermal printers. A certain quantity of BPA is released from all these materials and this chemical enters the environment, food chain and human body (Rubin, 2011).

Although BPA was evaluated by EFSA from a toxicological point of view as a substance which does not constitute a serious risk (EFSA, 2015), endocrinologists have classified BPA as an endocrine disruptor with considerable health risks (Vandenberg et al., 2010). Most of the population of developed countries have quantifiable levels of BPA in their organisms. The highest levels were detected in children and youth, lower levels were detected in adults (Calafat et al., 2008). This is an alarming finding, because it is suggested that children have increased sensitivity to the endocrine effects of BPA (Richter et al., 2007). Since BPA has even been detected in the bodies of pregnant women, amniotic fluid, placenta, and in the umbilical cord blood of newborn, there is concern about the effect of this substance on infants during prenatal development (Vandeberg et al., 2007a). Concentrations of BPA detected in the blood of the newborn in intensive care units were of an or-

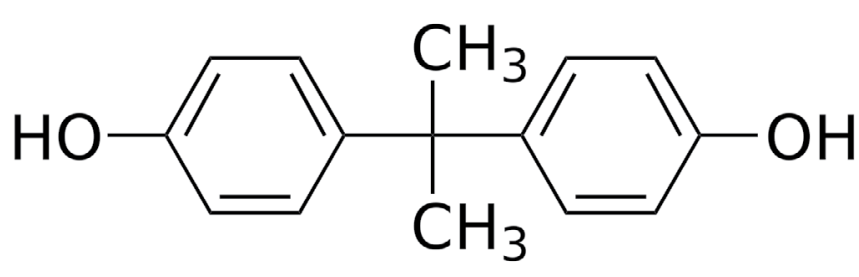

Figure 2. Bisphenol A (Source WikiMedia) https://upload.wikimedia.org/wikipedia/commons/f/f8/4\%2C4\%27-\%28propane-2\%2C2-diyl\%29diphenol_200.svg 
der of magnitude higher than those in healthy babies. In this case, the source of BPA is medical material made of plastics (Calafat et al., 2009).

Although food and beverages are considered as the major source of BPA, other inputs of BPA into the human body cannot be underestimated, such as the inhalation of contaminated air and the penetration of BPA through the skin. For example, high concentrations of BPA have been demonstrated in supermarket cashiers, who are in contact with the paper for thermal printers and banknote paper containing bisphenol S (Braun et al., 2011). BPA escapes into the air e.g. after the combustion of plastics (Fu-Kawamura, 2010).

\section{THE EFFECTS OF BPA}

BPA is known to act as xenoestrogen. Although BPA binds to classic oestrogen receptors much more weakly than estradiol, due to its actions on other target structures of estrogens, the overall estrogenic effects of BPA are comparable to estradiol (Watson et al., 2005). Some metabolites of BPA may even be more effective than BPA alone (Ben-Jonathan - Steinmetz, 1998). Moreover, the influence of BPA is not limited to its estrogenic effects, since it has a wider spectrum of action (Routledge et al., 2000) and acts e.g. as an antiandrogen (Kruger et al., 2008)

BPA acts on a wide variety of tissues and organs. The effect on neural tissue of the brain was clearly demonstrated by distinct effects on behaviour. For example, BPA prevents masculinisation of the brain during the fetal development of males (Patisauel et al., 2006) and interferes with the parental behaviour of males and females (Johnson et al., 2015). BPA disrupts embryonic and fetal development by affecting thyroid hormone signalling pathways (Heimeier - Shi, 2010) and also has a negative impact on the balance of glucocorticoid hormones (Prasanth et al., 2010). A number of effects of BPA, including its multigenerational effects, are apparently caused by BPAinduced epigenetic changes (Dolinoy et al., 2007; Bromer et al., 2010).

\section{BPA AND REPRODUCTION}

As an endocrine disruptor, BPA interferes significantly with reproduction in mammals. It has been shown in mice that daughters of mothers exposed to BPA have lower pregnancy rates and lower numbers of pups (Cabaton et al., 2011). The effect of BPA on the reproductive system is complex. BPA affects the whole hypothalamic-pituitary-gonadal axis. In females, it affects the secretion of gonadotropin-releasing hormone in the hypothalamus (Patisauel et al., 2006) and the functions of the pituitary gland (Ramos et al., 2003), ovaries (Hunt et al., 2003), uterus (Markey et al., 2005 ) and mammary glands (Vandenberg et al., 2007b).

In humans, elevated concentrations of BPA in women are linked to recurrent miscarriages (Sugiura-Ogasawara et al.,
2005) and premature births (Cantonwine et al., 2010). An apparent correlation between levels of BPA in the body and a reduced number of oocytes obtained from patients treated for infertility by assisted reproduction has been observed (Mok-Lin et al., 2010). The levels of BPA also correlate with increased incidence of reproductive system inflammation in post-menopausal women (Yang et al., 2009). There were significant correlations between elevated levels of BPA in the body and reduced sperm quality in men (Li et al., 2011).

\section{BPA AND OBESITY}

BPA belongs to the class of endocrine disrupters called obesogens which operates in the mammalian organism at many levels. As an obesogen, BPA contributes to changes in metabolism and its effects can result in overweight and obesity (Newbold et al., 2008). It also contributes to the disruption of the glucose metabolism (Alonso-Magdalena et al., 2006) and thus could elevate the risks of diabetes. Obesogenic effects of BPA could be involved in the proven correlation between levels of BPA in the body and the risk of cardiovascular disease (Melzer et al., 2010).

\section{BISPHENOL $S$}

Knowledge of the endocrine-disrupting effects of BPA led to the restricted use of this substance in many countries and its substitution with other chemicals. In many cases, bisphenol $\mathrm{S}$ is used as a substitute for BPA. This substance is currently not subject to rigorous regulation. At present, BPS is used in a wide range of products (Liao - Kannan, 2011) and its presence has been demonstrated in humans in many populations in economically developed countries (Liao et al., 2012). In many cases, the label "BPA-free" does not mean "bisphenolfree" because BPA is replaced with BPS. This fact is of particular concern (Glausiusz, 2014; Zimmerman - Anastas, 2015). Several studies have shown that BPS has significant endocrine-disrupting effects. Eladak et al. (2015) demonstrated

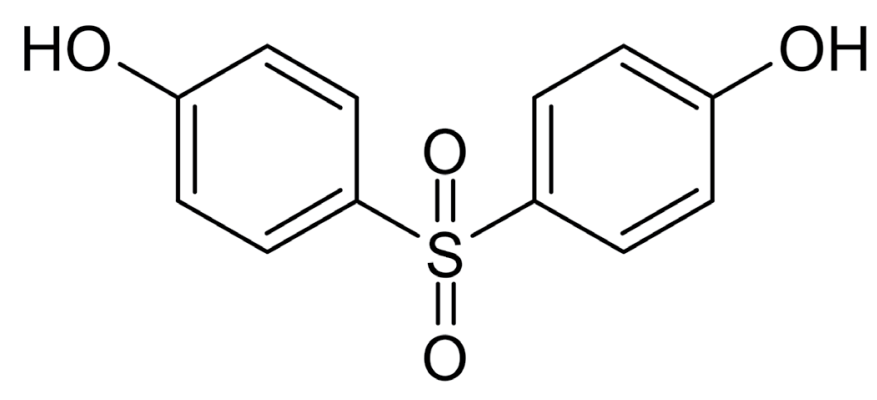

Figure 3. Bisphenol S (Source WikiMedia)

https://upload.wikimedia.org/wikipedia/commons/b/b8/Bisphenol_S.svg 


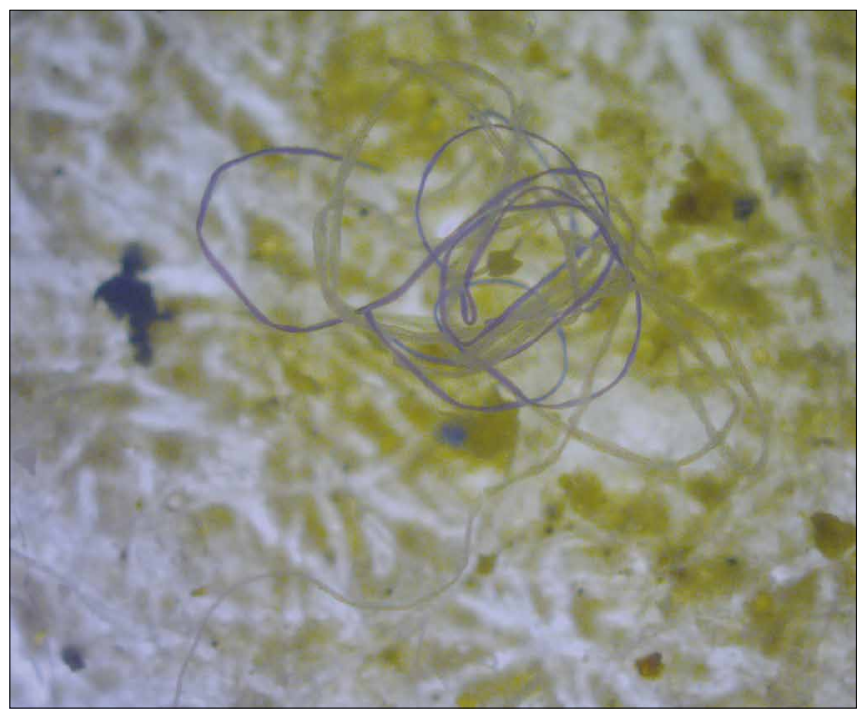

Figure 4. Microplastic fibers identified in the marine environment. (Source WikiMedia)

https://upload.wikimedia.org/wikipedia/commons/0/0d/Snap-40.jpg

a negative effect of BPS on mammalian testicular tissue. Vinas and Watson (2013) showed a negative effect of BPS on the function of the mammalian pituitary gland. The negative impact of BPS on reproduction in fish has been clearly demonstrated (Ji et al., 2013). Our preliminary results show that BPS also seriously disrupts the reproduction of mammalian females (Žalmanová et al., 2015).

\section{CONCLUSION}

It could appear that we are living the happy-end story in which the dangerous BPA pollutant has been replaced with a safer substance. But the situation is not as rosy as it seems at first glance. The substitution of BPA with BPS is referred to as a "regrettable substitution" (Zimmerman - Anastas, 2015). Unfortunately, this is not an isolated case. There are many similar "regrettable substitutions". For example, pyrethroids which replaced older insecticides, such as the organochlorines, organophosphates and carbamates, have shown a broad spectrum of undesirable side effects. It now appears that pyrethroids can also have a negative impact on mammals including man. In mammals, pyrethroids affect the functions of the brain (Viel et al, 2015) and reproductive organs (Petr et al., 2013).

There are some "happy-end stories" in the substitution of a detrimental chemical with a harmless one, e.g. the replacement of a wood preservative based on carcinogenic chromate copper arsenate (Landrigan et al., 2004) with the benign wood preservative, alkaline copper quaternary. However, we still face too many substitutions of chemicals which are steps from bad to worse. The story of bisphenol $S$ is just one such example.

\section{ACKNOWLEDGEMENT}

This work was supported by the Ministry of Agriculture of Czech Republic (NAZV - project No. QJ1510138) and by the Internal Grant Agency of the Czech University of Life Sciences Prague (CIGA - project No. 20132035).

\section{REFERENCES}

Alonso-Magdalena, P. - Morimoto, S. - Ripoll, C. - Fuentes, E. - Nadal, A. (2006): The estrogenic effect of bisphenol A disrupts pancreatic beta-cell function in vivo and induces insulin resistance. Environmental Health Perspectives, 114, 106-112.

Ben-Jonathan, N. - Steimetz, R. (1998): Xenoestrogens: the emerging story of bisphenol A. Trends in Endocrinology and Metabolism, 9, 124-128.

Braun, J. M. - Kalkbrenner, A. E. - Calafat, A. M. - Bernert, J. T. - Ye, X. Silva, M. J. - Barr, D. B. - Sathyanarayana, S. - Lanphear, B. P. (2011): Variability and predictors of urinary bisphenol A concentrations during pregnancy. Environmental Health Perspectives, 119, 131-137.

Bromer, J. G. - Zhou, Y. - Taylor, M. B. - Doherty, L. - Taylor, H. S. (2010): Bisphenol-A exposure in utero leads to epigenetic alterations in the developmental programming of uterine estrogen response. FASEB Journal, 24, 2273-2280.

Cabaton, N. J. - Wadia, P. R. - Rubin, B. S. - Zalko, D. - Schaeberle, C. M. - Askenase, M. H. - Gadbois, J. L. - Tharp, A. P. - Whitt, G. S. - Sonnenschein, C. - Soto, A. M.(2011): Perinatal exposure to environmentally relevant levels of bisphenol A decreases fertility and fecundity in CD-1 mice. Environmental Health Perspectives, 119, 547-552.

Calafat, A. M. - Ye, X. - Wong, L. Y. - Reidy, J. A. - Needham, L. L. (2008): Exposure of the U.S. population to bisphenol A and 4-tertiary-octylphenol. Environmental Health Perspectives, 116, 39-44.

Calafat, A. M. - Weuve, J. - Ye, X. - Jia, L. T. - Hu, H. - Ringer, S. - Huttner, K. - Hauser, R. (2009): Exposure to bisphenol A and other phenols in neonatal intensive care unit premature infants. Environmental Health Perspectives, 117, 639-644.

Cantonwine, D. - Meeker, J. D. - Hu, H. - Sánchez, B. N. - Lamadrid-Figueroa, H. - Mercado-García, A. - Fortenberry, G. Z. - Calafat, A. M. Téllez-Rojo, M. M. (2010): Bisphenol a exposure in Mexico City and risk of prematurity: a pilot nested case control study. Environmental Health, 9,62 .

Colborn, T. (2004): Endocrine disruption over view: are males at risk? Advances in Experimental Medicine and Biology, Volume 545, 189-201.

Corcoran, P. L. - Moore, C. J. - Jazvac, K. (2014): An anthropogenic marker horizon in the future rock record. Geological Society of America Today, 24, 4-8.

Dolinoy, D. C. - Huang, D. - Jirtle, R. L. (2007): Maternal nutrient supplementation counter acts bisphenol A-induced DNA hypomethylationin early development. Proceedings of the National Academy of Sciences USA, 104, 13056-13061.

Eladak, S. - Grisin, T. - Moison, D. - Guerquin, M. J. - N'Tumba-Byn, T. Pozzi-Gaudin, S. - Benachi, A. - Livera, G. - Rouiller-Fabre, V. - Habert, R. (2015): A new chapter in the bisphenol A story: bisphenol S and bisphenol $\mathrm{F}$ are not safe alternatives to this compound. Fertility and sterility, $103,11-21$.

European Food and Safety Agency (2012): EFSA Scientific Colloquium Summary Report, 17, 64.

European Food and Safety Agency (2015): EFSA Journal, 13, 3978.

Fu, P. - Kawamura, K. (2010): Ubiquity of bisphenol A in the atmosphere. Environmental Pollution, 158, 3138-3143.

Glausiusz, J. (2014): Toxicology: The plastics puzzle. Nature, 508, 306-308.

Heimeier, R. A. - Shi, Y. B. (2010): Amphibian metamorphosis as a model for studying both the morphological effects and the underlying molecular basis of endocrine disruptors on vertebrate development: A case study with the xenoestrogen bisphenol A. General and Comparative Endocrino$\log y, 168,181-189$. 
Hunt, P. A. - Koehler, K. E. - Susiarjo, M. - Hodges, C. A. - Ilagan, A. - Voigt, R. C. - Thomas, S. - Thomas, B. F. - Hassold, T. J. (2003): Bisphenol a exposure causes meiotic aneuploidy in the female mouse. Current Biology, $13,546-553$.

Jambeck, J. R. - Geyer, R. - Wilcox, C. - Siegler, T. R. - Perryman, M. - Andrady, A. - Naryan, R. - Law, K. L. (2015): Plastic waste inputs from land into the ocean. Science, 347, 768-771.

Ji, K. - Hong, S. - Chou, Y. K. K. (2013): Effects of Bisphenol S Exposure on Endocrine Functions and Reproduction of Zebrafish. Environmental Science and Technology 47, 8793-8800.

Johnson, S. A. - Javurek, A. B. - Painter, M. S. - Peritore, M. P. - Ellersieck, M. R. - Roberts, R. M. - Rosenfeld, C. S. (2015): Disruption of Parenting Behaviors in California Mice, a Monogamous Rodent Species, by Endocrine Disrupting Chemicals. PLoS ONE, 10, doi:10.1371/journal.pone.0126284.

Kruger, T. - Long, M. - Bonefeld-Jørgensen, E. C. (2008): Plastic components affect the activation of the aryl hydrocarbon and the androgen receptor. Toxicology, 246, 112-123.

Landrigan, P. J. - Kimmel, C. A. - Correa, A. - Eskenazi, B. (2004): Children's health and the environment: public health issues and challenges for risk assessment. Environmental Health Perspectives, 112, 257-265.

Li, D. J. K. - Zhou, Z. - Miao, M. - He, Y. - Wang, J. - Ferber, J. (2011): Urine bisphenol-A (BPA) level in relation to semen quality. Fertility and Sterility, 95, 625-630.

Liao, C. - Liu, F. - Alomirah, H. - Loi, V. D. - Mohd, M. A. - Moon, H. B. (2012): Bisphenol $S$ in urine from the United States and seven Asian countries: occurrence and human exposures. Environmental Science and Technology, 46, 6860-6866.

Liao, C. - Kannan, K. (2011): Widespread occurrence of bisphenol A in paper and paper products: implications for human exposure. Environmental Science and Technology, 45, 9372-9379.

Markey, C. M. - Wadia, P. R. - Rubin, B. S. - Sonnenschein, C. - Soto, A. M. Melzer, D. (2005): Long-Term Effects of Fetal Exposure to Low Doses of the Xenoestrogen Bisphenol-A in the Female Mouse Genital Tract. Biology of Reproduction, 72, 1344-1351.

Mok-Lin, E. - Ehrlich, S. - Williams, P. L. - Petrozza, J. - Wright, D. L. - Calafat, A. M. - Ye, X. - Hauser, R. (2010): Urinary bisphenol a concentrations and ovarian response among women undergoing IVF. International Journal of Andrology, 33, 385-393.

Monastersky, R. (2015): “Anthropocene: The human age." Nature, 519 (7542), $144-147$.

Newbold, R. R. - Padilla-Banks, E. - Jefferson, W. N. - Heindel, J. J. (2008): Effects of endocrine disruptors on obesity. International Journal of Andrology, 31 (2), 201-208.

Patisauel, H. B. - Fortino, A. E. - Polston, E. K. (2006): Neonatal genistein or bisphenol-A exposure alters sexual differentiation of the AVPV. Neurotoxicology and Teratology, 28, 111-118.

Petr, J. - Chmelíková, E. - Žalmanová, T. - Tůmová, L. - Kheilová, K. Kučerová-Chrpová, V. - Jílek, F. (2013): Pyrethroids cypermethrin, deltamethrin and fenvalerate have different effects on in vitro maturation of pig oocytes at different stages of growth, Animal, 7, 134-142.

Prasanth, G. K. - Divya, L. M. - Sadavisan, C. (2010): Bisphenol-A can bind to human glucocorticoid receptor as an agonist: an in silico study. Journal of Applied Toxicology, 30, 769-774.

Ramos, J. G. - Varayoud, J. - Kass, L. - Rodríguez, H. - Costabel, L. - MuñozDe-Toro, M. - Luque, E. H. (2003): Bisphenol A induces both transient and permanent histofunctional alterations of the hypothalamic-pituitarygonadal axis in prenatally exposed male rats. Endocrinology, 144, 32063215.

Rochman, C. M. - Browne, M. A. - Halpern, B. S. - Hentschel, B. T. - Hoh, E. - Karapanagioti H. K. - Rios-Mendoza, L. M. - Takada, H. - The, S. Thompson, R. S. (2013): Classify plastic waste as hazardous. Nature, 494, 169-171.

Richter, C. - Birnbaum, L. S. - Farabollini, F. - Newbold, R. - Rubin, B. S. Talsness, C. E. - Vandenbergh, J. G. - Walser-Kuntz, D. R. - vom Saal, F. S. (2007): In vivo effects of bisphenol A in laboratory rodent studies. Reproductive Toxicology, 24, 199-224.

Routledge, E. J. - White, R. - Parker, M. G. - Sumpter, J. P. (2000): Differential effects of xenoestrogens on coactivator recruitment by estrogen receptor (ER) alpha and ER beta. Journal of Biological Chemistry, 275, 35986-35993.
Rubin, B. S. (2011): Bisphenol A: An endocrine disruptor with widespread exposure and multiple effects. Journal of Steroid Biochemistry and Molecular Biology, 127, 27-34.

Sugiura-Ogasawara, M. - Ozaki, Y. - Sonta, S. - Makino, T. - Suzumori, K. (2005): Exposure to bisphenol A is associated with recurrent miscarriage. Human Reproduction, 20, 2325-2329.

Trasande, L. - Zoeller, R. T. - Hass, U. - Kortenkamp, A. - Grandjean, P. - Myers, J. P. - DiGangi, J. - Bellanger, M. - Hauser, R. - Legler, J. - Skakkebaek, N. E. - Heindel, J. J. (2015): Estimating burden and disease costs of exposure to endocrine-disrupting chemicals in the European Union. Journal of Clinical Endocrinology and Metabolism, 100, 1245-55.

Vandenberg, L. N. - Colborn, T. - Hayes, T. B. - Heindel, J. J. - Jacobs, D. R. Jr. - Lee, D. H. - Shioda, T. - Soto, A. M. - vom Saal, F. S. - Welshons, W. V. (2012): Hormones and endocrine-disrupting chemicals: low-dose effects and nonmonotonic dose responses. Endocrine Reviews, 33, 378-455.

Vandenberg, L. N. - Chahoud, I. - Heindel, J. J. - Padmanabhan, V. Paumgartten, F. J. - Schoenfelder, G. (2010): Urinary, circulating, and tissue biomonitoring studies indicate widespread exposure to bisphenol A. Environmental Health Perspectives, 118, 1055-1070.

Vandenberg, L. N. - Hauser, R. - Marcus, M. - Olea, N. - Welshons, W. V. (2007a): Human exposure to bisphenol A (BPA). Reproductive Toxicology, 24, 139-177.

Vandenberg, L. N. - Maffini, M. V. - Wadia, P. R. - Sonnenschein, C. - Rubin, B. S. - Soto, A. M. (2007b): Exposure to environmentally relevant doses of the xenoestrogen bisphenol-A alters development of the fetal mouse mammary gland. Endocrinology, 148, 116-127.

Viel, J. F. - Warembourg, C. - Le Maner-Idrissi, G. - Lacroix, A. - Limon, G. Rouget, F. - Monfort, C. - Durand, G. - Cordier, S. - Chevrier, C. (2015) Pyrethroid insecticide exposure and cognitive developmental disabilities in children: The PELAGIE mother-child cohort. Environment International, 82, 69-75.

Viňas, R. - Watson, C. S. (2013): Bisphenol S disrupts estradiol-induced nongenomic signaling in a rat pituitary cell line: effects on cell functions. Environmental Health and Perspectives, 121, 352-358.

Watts, A. J. R. - Lewis, C. - Goodhead, R. M. - Beckett, S. J. - Moger, J. - Tyler, C. R. - Galloway, T. (2014): Uptake and retention of microplastics by the shore crab Carcinus maenas. Environmental Science and Technology, 48, 8823-8830.

Watson, C. S. - Bulayeva, N. N. - Wozniak, A. L. - Finnerty, C. C. (2005): Signaling from the membrane via membrane estrogen receptor-alpha: estrogens, xenoestrogens, and phytoestrogens. Steroids, 70, 364-371.

Wright, S. L. - Thompson, R. C. - Galloway, T. S. (2013): The physical impacts of microplastics on marine organisms: a review. Environmental Pollution, $178,483-492$.

Yang, Y. J. - Hong, Y. C. - Oh, S. Y. - Park, M. S. - Kim, H. - Leem, J. H. - Ha, E. H. (2009): Bisphenol A exposure is associated with oxidative stress and inflammation in postmenopausal women. Environmental Research, 109, 797-801.

Zimmerman, J. B. - Anastas, P. T. (2015): Toward substitution with no regrets. Science, $347,1198-1199$

Žalmanová, T. - Hošková, K. - Nevoral, J. - Zámostná, K. - Petr, J. (2015): Vliv bisfenolu S na meiotické zrání prasečích oocytů, Bilaterálne vedecké symposium Endokrinné disruptory, Bratislava 04.-05.2015, 37.

\section{AUTHORS}

Tereza ŽALMANOVÁ, Ph.D. (18.11.1976, Praha)

She works as researcher at the Department of Veterinary Sciences, Czech University of Life Sciences Prague. She points out the study of endocrine disruptors' effect on female reproduction, currently emphasized on biological impact of bisphenols on oocyte maturation and fertilization.

Kristýna HOŠKOVÁ, Ph.D. (19.10. 1982, Praha)

She is researcher at the Department of Veterinary Sciences, Czech University of Life Sciences Prague. She is dealing with effects of endocrine disruptors on oocyte maturation. 
Jan NEVORAL, Ph.D. (23.8. 1986, Jilemnice)

$\mathrm{He}$ is head of Laboratory of Reproductive Medicine in Biomedical Center in Pilsen, focused on mammalian gametogenesis and embryonic development, including endocrine disruption testing.

Šárka PROKEŠOVÁ (8.10. 1988, Kladno)

She is Ph.D. student at the Department of Veterinary Sciences, Czech University of Life Sciences Prague. The aim of her study is the evaluation of bisphenol $\mathrm{S}$ effect on oocyte maturation.

Kateřina ZÁMOSTNÁ (13.3. 1990, Praha)

She is Ph.D. student at the Department of Veterinary Sciences, Czech University of Life Sciences Prague. The aim of her thesis is the study of fertilization and early embryonic development of pigs.
Zora KOTÍKOVÁ, Ph.D. (14.4. 1981, Praha)

She is researcher at the Department of Chemistry, Czech University of Life Sciences Prague. She is dealing with analysis of environmental polutants in plant- and animal-originated materials.

Jaroslav PETR, Ph.D., Professor (3.8. 1958, Kolín)

$\mathrm{He}$ works at the Institute of Animal Science, where he is engaged in the studies of animal reproduction and animal biotechnology. He is Professor at the Czech University of Life Sciences Prague. He is senior leader of research group focused on the effects of endocrine disruptors on mammalian fertility. 